\title{
Comparative study of two skeletal maturation evaluation indexes
}

\author{
Estudo comparativo de dois índices de estimativa da \\ maturação esquelética
}

\begin{abstract}
Purpose: The present work consists of a comparative study of two indexes of skeletal maturation: the carpal index (SMI) and the vertebral index (CVMI) and verification of the reliability of the vertebral index in the determination of the stages of the skeletal maturation.

Methods: Radiographies from the dental records of treated patients from Universidade do Sul de Santa Catarina (UNISUL) were used. The sample was composed of 158 radiographies comprising seventy-nine carpal and seventy-nine lateral cephalometric radiographies of patients of both genders between six and eighteen of age. The carpal radiographies were analyzed using Martins' method and the lateral cephalometric, according to Baccetti, Franchi and McNamara Jr.

Results: The Spearman's correlation test results showed a significant correlation coefficient of 0.616 between SMI and CVMI and the Pearson's test, of 0.698 for both genders $(P<0.0001)$. The correlation between the indexes and the chronological age was 0.775 for SMI using Spearman's test, and 0.974 using Pearson's correlation test. For the CVMI, Spearman's correlation was 0.563 and Pearson's was 0.717 , showing that there is a statistically significant correlation.

Conclusion: The SMI is the safest and most trustworthy method to evaluate the skeletal maturation, although the CVMI can be used as a substitute method when there is conversance with the morphologic alterations of the vertebrae and when the carpal radiography is not available in the patient's orthodontic records.
\end{abstract}

Key words: Cervical vertebrae; age determination by skeleton; radiography; hand bones

\section{Resumo}

Objetivo: Comparar o índice de maturação esquelética carpal (IMC) e o índice vertebral (IMV) e verificar a confiabilidade do IMV na determinação desta maturação.

Metodologia: Utilizou-se radiografias dos prontuários da disciplina de Ortodontia da UNISUL. A amostra foi composta por 158 radiografias, sendo 79 carpais e 79 cefalométricas em norma lateral, de pacientes com idades variando entre 6 e 18 anos, de ambos os sexos. Para a determinação do IMC utilizou-se o método de Martins e para o IMV, o de Baccetti, Franchi e McNamara Jr.

Resultados: Os testes de correlação de Spearman e Pearson mostraram um índice entre IMC e IMV de 0,616 e 0,698, respectivamente, correlação estatisticamente significante para ambos os sexos $(P<0,0001)$. A correlação de Spearman e de Pearson entre o IMC e a idade cronológica foi de 0,775 e 0,974, respectivamente. Já entre o IMV e a idade cronológica foi de 0,563 e 0,717, respectivamente, uma correlação também estatisticamente significante.

Conclusão: O IMC é o método mais seguro e confiável de avaliação da maturação esquelética, porém o IMV pode ser usado como método substituto quando houver familiaridade com as alterações morfológicas das vértebras e quando a radiografia carpal não estiver disponível na documentação ortodôntica.

Palavras-chave: Vértebras cervicais; determinação da idade pelo esqueleto; radiografia; ossos da mão

\section{Daiany Warmeling a \\ Karina Marcos Rodrigues a \\ Michella Dinah Zastrow ${ }^{b}$ \\ Guilherme Thiesen c}

a Curso de Odontologia, UNISUL, Tubarão, SC, Brasil

bDisciplinas de Radiologia e Estomatologia, UNISUL, Tubarão, SC, Brasil

c Disciplina de Ortodontia, UNISUL ,Tubarão, SC, Brasil
Correspondence:

Michella Dinah Zastrow

Universidade do Sul de Santa Catarina

Curso de Odontologia

Avenida José Acácio Moreira, 787

Bairro Dehon

Tubarão, SC - Brasil

88704-900

E-mail: michella.costa@unisul.br

Received: August 13, 2009

Accepted: March 31, 2010

Conflict of Interest Statement: The authors state that there are no financial and personal conflicts of interest that could have inappropriately influenced their work.

Copyright: (C) 2010 Warmeling et al.; licensee EDIPUCRS. This is an Open Access article distributed under the terms of the Creative Commons AttributionNoncommercial-No Derivative Works 3.0 Unported License. 


\section{Introduction}

Orthodontics has its activity largely concentrated on the interpretation of factors related to individuals' facial growth and development. The evaluation of these factors from the clinical point of view is fundamental for diagnosis and correct treatment planning (1). It is, therefore, of great value to estimate the patient's biological age, since chronological age is not a reliable parameter in evaluating the skeletal maturation stage (2).

The orthodontic treatment tries to coordinate the mechanical procedures with the craniofacial alterations determined by the intense growth that takes place during puberty (3). This intense growth is called pubertal growth spurge (PGS). This period is of the utmost importance in orthopedic orthodontic treatment, especially in cases of discrepancies of skeletal and dento-skeletal nature, because unlike dental disharmonies that can be solved at any time, if such divergences are not treated in this phase, the desired treatment results may not be achieved (4).

PGS exhibits an increase in speed usually between 9 and 14 years of age. During approximately 2 years of the PGS period, there is a moment of minimum prepubertal growth (MPP), which characterizes the beginning of PGS, and 2 different growth phases, one accelerating and another decelerating, which are separated by a moment of maximum speed called peak of pubertal growth speed (PPGS) (3).

Many authors have attempted to determine the best indicators of the maturation degree. Secondary sex characteristics (5), chronological age (6), dental development $(7,8)$, height (6), weight (6), skeletal development (9) and vertebrae development $(10,11)$ are some of the parameters that have been used to identify the different growth phases.

The bone age, also known as bone maturity age, has been the indicator most commonly used in studies on growth and development, and considered as a true record of the biological age. Its determination is based on the skeletal changes during the development, which can all be evaluated through radiographies of selected areas of the body during the growth period (12).

The analysis of the carpal radiography for the determination of the skeletal maturation is the most used method for studies on craniofacial growth and development (9). The ample use of this type of radiography is attributable to the fact that the carpal region presents a great number of ossification centers in a relatively small area, the easiness of application of the radiographic technique, and the small amount of radiation to which the patient is exposed during the accomplishment of the examination (4).

Other methods, such as the observation of the cervical vertebrae maturation through lateral cephalometric radiographies have been studied, since the utilization of these radiographies lessens the patients' exposure to ionizing radiations and because they are already included in the routine orthodontic documentation, as they determine a decrease in costs for the attainment of the documentation and simplify the diagnostic resources available $(4,13)$.
Many authors $(10,11,13,14)$ have accomplished studies on the cervical vertebrae development for the determination of the individual's skeletal maturation.

Thence, the objective of this study was to compare two skeletal maturation indexes, the carpal index and the vertebral index, and verify the trustworthiness of the vertebral index for the determination of the skeletal maturation stages.

\section{Methodology}

This research was carried through after submission to and approval of the UNISUL Research Ethics Committee, under registration number 08.498.4.02 III.

Radiographies from the Universidade do Sul e Santa Catarina (UNISUL) orthodontic handbooks were utilized. The handbooks that presented 1 carpal and 1 lateral cephalometric radiography made on the same date were selected. Handbooks that presented unsatisfactory radiographies concerning technique and processing aspects were excluded, together with those through which it was not possible to visualize $\mathrm{C} 2, \mathrm{C} 3$ and $\mathrm{C} 4$ vertebrae.

Thus, a sample of 158 radiographies consisting of 79 carpal and lateral 79 cephalometric radiographies of patients with ages varying from 6 to 18 years was obtained.

An examiner was then calibrated to make the evaluation of the radiographies obtained. At a first moment, the calibration consisted of the analysis of 10 radiographies presenting all the ideal conditions of interpretation. Seven days later, the same the 10 radiographies were reevaluated. With these data, the Kappa test was carried through, reaching an agreement of $80 \%$ for SMI and CVMI.

The radiographies of the two groups were numbered and masked by another Professional to avoid patients' identification and prevent a conceivable biased analysis by the observer.

\section{Evaluation of Skeletal Radiographies}

The skeletal maturation index (SMI) was determined through the evaluation of the carpal radiographies, according to Martins' method (1979). The bone age was defined through the evaluation of the stages of the different ossification centers in the hand and fist, as described herein below and shown in Fig. 1:

Stage $1-\mathrm{DP}=$ width of epiphysis distal phalanges is equal to the width of its diaphysis;

Stage $2-\mathrm{PP}=$ width of epiphysis proximal phalanges is equal to the width of its diaphysis;

Stage $3-\mathrm{MP}=$ width of epiphysis medial phalanges is equal to the width of its diaphysis;

Stage $4-\mathrm{G} 1=$ beginning of the appearance of the radioopaque hook in the hooked bone;

Stage $5-$ Psi $=$ visualization of the pisiform bone;

Stage $6-\mathrm{R}=$ width of radial epiphysis is equal to the width of its diaphysis;

Stage $7-$ DP cap $=$ epiphysis capping in the distal phalanges; Stage $8-\mathrm{S}=$ visualization of the sesamoid bone; 


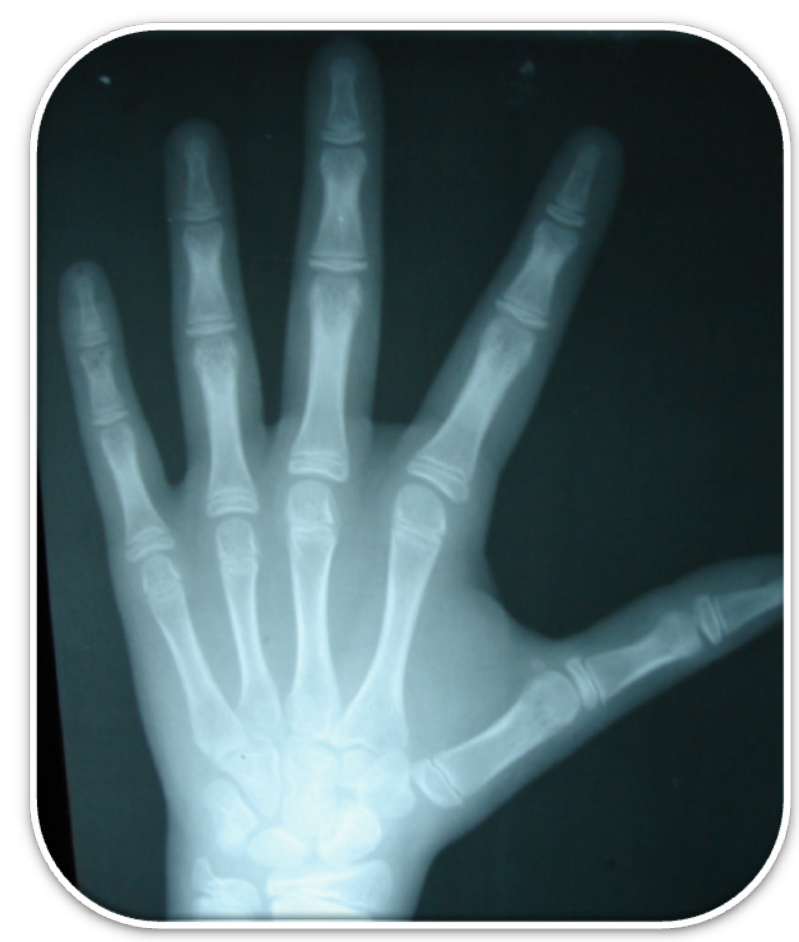

Fig. 1. Hand and fist radiography of an individual that was in SMl stage 8 . The sesamoid bone is observed.

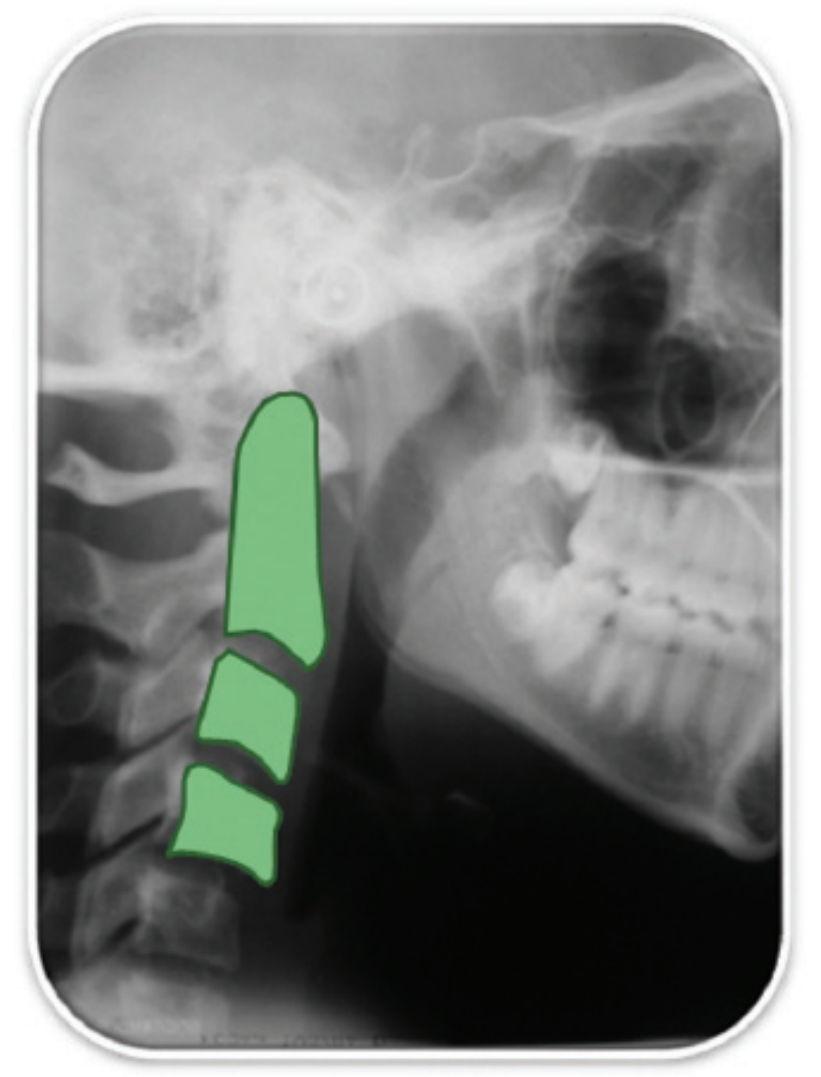

Fig. 2. Lateral cephalometric radiography of an individual in CVMI stage 3. It can be observed the presence of concavities on C2, C3 and C4 lower borders. C3 and C4 vertebrae bodies are rectangular with a broader horizontal width.
Stage 9 - G2 = radio-opaque kook clearly visible in body of the hooked bone;

Stage $10-$ PP cap = epiphysis capping in the proximal phalanges;

Stage $11-$ MP cap = epiphysis capping in the medial phalanges;

Stage $12-\mathrm{R}$ cap = epiphysis capping in the radius;

Stage $13-\mathrm{M}=$ menarche moment. This stage could not be evaluated in this study, because it is not considered an ossification center, reason why it is not visualized in the radiography;

Stage $14-$ DP iu = beginning of the epiphysis union in the distal phalanges;

Stage $15-\mathrm{PP}$ iu $=$ beginning of the epiphysis union in the proximal phalanges;

Stage $16-\mathrm{MP}$ iu = beginning of the epiphysis union in the medial phalanges;

Stage $17-$ DP tu = total epiphysis union in the distal phalanges;

Stage $18-$ PP tu $=$ total epiphysis union in the proximal phalanges;

Stage 19-MP tu = total epiphysis union in the distal phalanges;

Stage $20-\mathrm{R}$ tu $=$ total epiphysis union in the radius.

\section{Evaluation of lateral cephalometric radiographies}

The cervical vertebrae maturation index (CVMI) was determined through the evaluation of the lateral cephalometric radiographies, according to method of Baccetti, Franchi and McNamara Jr (22). Vertebrae C2, C3 and C4 were drawn on acetate paper on the surface of the lateral cephalometric radiographies. With the drawings accomplished, the vertebrae alterations were then defined. Later, the patient was classified within the 5 stages considered by the authors, as described herein below and exemplified in Fig. 2:

Stage 1 - C2, C3 and C4 lower vertebraae body borders are flat. In some cases, there may be a concavity on the lower border of C2. C3 and C4 vertebrae bodies are trapezoidal; Stage 2 - Presence of concavities on $\mathrm{C} 2$ and lower borders. The vertebrae bodies of $\mathrm{C} 3$ and $\mathrm{C} 4$ can be either trapezoidal or rectangular, with a broader horizontal length;

Stage 3 - Presence of concavities on C2, C3 and C4 lower borders. $\mathrm{C} 3$ and $\mathrm{C} 4$ vertebrae bodies are rectangular with a broader horizontal width;

Stage 4 - Presence of concavities on C2, C3 and C4 lower borders. C3 and C4 vertebrae bodies are square, and those that are not remain rectangular with a broader horizontal length.

Stage 5 - Concavities still evident on C2, C3 and C4 lower borders. The body of either $\mathrm{C} 3$ or $\mathrm{C} 4$ is rectangular. One has a broader vertical length and the other is square.

The stages of maturation obtained through the analysis of each index (SMI x CVMI) were compared to verify if there was correlation between them. The creation of a comparative graph that took into consideration the results obtained from both indexes and that resembled each patient's PCS was 
essential. In that manner, the stages present in the Martins' curve (1979) were tabulated in the CVMI stages (Fig. 3) (4): The data were tabulated and then analyzed using descriptive statistics and using Spearman's and Pearson's correlation test among the variables of the study (SMI, CVMI and chronological age). The confidence interval adopted was $95 \%$. The $P$-value lower than 0.05 was considered statistically significant.

\begin{tabular}{|c|c|c|}
\hline Classification & CVMI & SMI \\
\hline 1 & Stage 1 & 1 a 8 \\
\hline 2 & Stage 2 & 9 a 12 \\
\hline 3 & Stage 3 & 13 a 15 \\
\hline 4 & Stage 4 & 16 a 19 \\
\hline 5 & Stage 5 & 20 \\
\hline
\end{tabular}

Fig. 3. Association between SMI and CVMI.

\section{Results}

Seventy-nine carpal and 79 lateral cephalometric radiographies pertaining to 46 female and 23 male patients with ages varying from 6 to 18 years were analyzed (average of 9.84 years; $\mathrm{DP}=2.53)$.

Sixty radiographies (75.9\%), 27 (34.1\%) pertaining to male and 33 female (41.7\%) individuals, were classified within stages 1-8 of the Martins' curve (1979). Ten radiographies $(12.5 \%)$ within stages $9-12 ; 7$ radiographies $(8.86 \%)$ stages 16-19; and 2 (2.4\%) within stage 20.

Thirty-eight radiographies $(48.1 \%)$ pertaining to 16 male and 22 to female patients were classified within stage 1 of
CVMI; 17 (21.5\%) within stage 2; 19 (24\%) within stage 3; $5(6.3 \%)$ within stage 4 ; and none within stage 5 .

Sixty radiographies (75.9\%) were classified within SMI stages from 1 to 8 , i.e., $26(32.9 \%)$ pertaining to patients between the ages of 6 and $8 ; 32(40.5 \%)$ to patients between the ages of 9 and 12; and 2 between the ages of 13 and 15. Ten radiographies $(12.5 \%)$ were within stages $9-12$; $7(8.8 \%)$ pertaining to patients between the ages of $9-12$ and $3(3.7 \%)$ to patients between the ages of 13 and 15 . Seven radiographies $(8.8 \%)$ were classified within stages $16-19$ : $1(1.2 \%)$ pertaining to a patient with age between 9 and 12 years and $6(7.5 \%)$ to patients between the ages of 13 and 15 (Table 1).

Thirty-eight radiographies $(48.1 \%)$ were classified within CVMI stage 1: $21(26.6 \%)$ pertaining to patients between the ages of 6 and $8 ; 16(20.3 \%)$ to patients between the ages of 9 and 12; and $1(1.2 \%)$ to 1 patient aged between 13 and 15 years old. Seventeen radiographies $(21.5 \%)$ were classified within stage $2: 4(5.1 \%)$ pertaining to patients aged between 6 and 8 years and $13(16.5 \%)$ between 9 and 12 years. Nineteen radiographies (24\%) were classified within stage 3: 1 belonging to a patient between the ages of 6 and 8 years, $11(13.9 \%)$ to patients between the ages of 9 and 12 and $7(8.9 \%)$ to patients between the ages of 13 and 15. Five radiographies $(6.3 \%)$ were classified within stage 4: $3(3.8 \%)$ pertaining to patients between the ages of 13 and 15 ; and $2(2.5 \%)$ to patients with 15 years of age or older.

Spearman's correlation test showed a coefficient of correlation between the SMI and the chronological age of $0.775(P<0.0001)$, while the Pearson's correlation test showed a coefficient correlation of 0.974 .

Table 1. Absolute and relative distribution of SMI according to age. Tubarão, 2009.

\begin{tabular}{|c|c|c|c|c|c|c|c|c|c|c|}
\hline \multicolumn{11}{|c|}{ Carpal Maturation Index } \\
\hline \multirow{3}{*}{ AGE } & \multicolumn{8}{|c|}{ STAGES } & \multirow{2}{*}{\multicolumn{2}{|c|}{ Total }} \\
\hline & \multicolumn{2}{|c|}{$1-/ 8$} & \multicolumn{2}{|c|}{$8-/ 12$} & \multicolumn{2}{|c|}{$15-/ 19$} & \multicolumn{2}{|c|}{$19-/ 20$} & & \\
\hline & $\mathrm{n}$ & $\%$ & $\mathrm{n}$ & $\%$ & $\mathrm{n}$ & $\%$ & $\mathrm{n}$ & $\%$ & $\mathrm{n}$ & $\%$ \\
\hline $05-/ 08$ & 26 & 32.91 & - & - & - & - & - & - & 26 & 32.91 \\
\hline $08-/ 12$ & 32 & 40.51 & 7 & 8.86 & 1 & 1.27 & - & - & 40 & 50.63 \\
\hline $12-/ 15$ & 2 & 2.53 & 3 & 3.80 & 6 & 7.59 & - & - & 11 & 13.92 \\
\hline $15-/$ & - & - & - & - & - & - & 2 & 2.53 & 2 & 2.53 \\
\hline Total & 60 & 75.95 & 10 & 12.66 & 7 & 8.86 & 2 & 2.53 & 79 & 100.00 \\
\hline
\end{tabular}

Table 2. Absolute and relative distribution of CVMI according to age. Tubarão, 2009.

\begin{tabular}{|c|c|c|c|c|c|c|c|c|c|c|}
\hline \multicolumn{11}{|c|}{ Vertebrae Maturation Index } \\
\hline \multirow{3}{*}{ AGE } & \multicolumn{8}{|c|}{ STAGES } & \multirow{2}{*}{\multicolumn{2}{|c|}{ Total }} \\
\hline & \multicolumn{2}{|c|}{1} & \multicolumn{2}{|c|}{2} & \multicolumn{2}{|c|}{3} & \multicolumn{2}{|c|}{4} & & \\
\hline & $\mathrm{n}$ & $\%$ & $\mathrm{n}$ & $\%$ & $n$ & $\%$ & $\mathrm{n}$ & $\%$ & $n$ & $\%$ \\
\hline $05-/ 08$ & 21 & 26.58 & 4 & 5.06 & 1 & 1.27 & - & - & 26 & 32.91 \\
\hline $08-/ 12$ & 16 & 20.25 & 13 & 16.46 & 11 & 13.92 & - & - & 40 & 50.63 \\
\hline $12-/ 15$ & 1 & 1.27 & - & - & 7 & 8.86 & 3 & 3.80 & 11 & 13.92 \\
\hline $15-/$ & - & - & - & - & - & - & 2 & 2.53 & 2 & 2.53 \\
\hline Total & 38 & 48.10 & 17 & 21.52 & 19 & 24.05 & 5 & 6.33 & 79 & 100.00 \\
\hline
\end{tabular}


Spearman's correlation test showed a coefficient of correlation between the SVMI and the chronological age of $0.563(P<0.0001)$ and Pearson's correlation test, a correlation of 0.717 .

Spearman's correlation test showed a coefficient of correlation between the SVMI and the SMI of 0.616 $(P<0.0001)$ and Pearson's correlation test, a correlation of 0.698 . This reveals that there is a statistically significant correlation for the determination of bone maturation, as shown in Fig. 4.

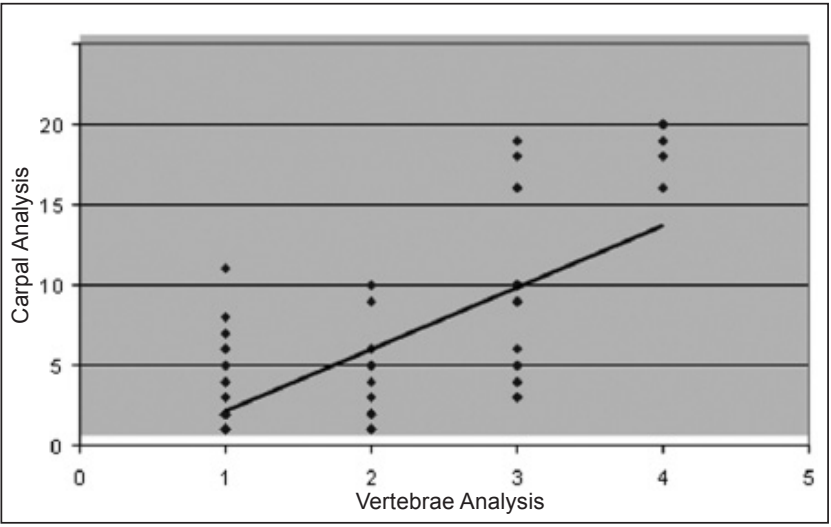

Fig. 4. Scatter plot of the carpal and vertebrae analysis in all patients. Tubarão, 2009.

\section{Discussion}

Several comparative studies between the SMI and the CVMI indexes have been conducted to determine the stage of development of an individual. The determination of the stage of skeletal maturation through the SMI and CVMI is extremely important for the accomplishment of a correct diagnosis and orthodontic-orthopedic planning. Some researchers $(8,14,15-20)$ have reported the occurrence of a positive and statistically significant correlation between the two methods in works that compared these two indices, thus corroborating the findings of this study. However, examining the values found for the Spearman's and Pearson's correlations, whereby SMI and CVMI indices were correlated with the chronological age, it can be observed that the carpal evaluation coefficients and chronological age were slightly higher than the evaluation coefficients of the cervical vertebrae, as substantiated by the findings from the studies conducted by Santos and Almeida (20). This fact indicates that the carpal evaluation method showed an assimilation and reproducibility greater than the cervical vertebrae evaluation method.

When the skeletal and vertebrae analyses were correlated with the chronological age, both presented a statistically significant correlation in the evaluation of all participants. This result suggests that the analyses seem to be compatible with the chronological age, in agreement with the studies accomplished by Paiva et al. (21) and Generoso et al. (6), which substantiated that the progression of the maturation stages is in accordance with the increase in chronological age. This result is in opposition to the observations made by Fishman (5), whereby the chronological age was not correlated with the bone age, because the latter can lag behind or be in advance of the chronological age. This fact can be related with external and internal factors that can interact with the variability of the general and craniofacial growth, such as sex, race, genetic predisposition, diseases, and climatic, nutritional, psychosocial, and socioeconomic conditions.

According to Generoso et al. (6), the PGS phase is the best time to carry out an orthodontic or an orthopedic treatment on an individual. According to Martins (3), the beginning of PGS occurs almost at the same time of SMI stage 4, and according to Baccetti, Franchi and McNamara Jr (22), it occurs about the same time of CVMI stage 2. In the present study, 22 patients $(27.8 \%$ of the sample) were between SMI stages 4 to 8 and 17 patients (21.5\%) within CVMI stage 2. This finding shows the correlation between the two bone maturation methods.

A great part of the sample (49.3\%) presented was within SMI stages 1 to 3 of the Martins' curve (3) and $48.1 \%$ within CVMI stage 1 according to Baccetti, Franchi and McNamara Jr (22). This result is probably imputable to the fact that the average age of the patients was 9.85 years, corresponding to the initial stages of bone development, suggesting a correlation between these two methods (17).

One of the limitations on the use of CVMI according to the method of Baccetti, Franchi and McNamara Jr (22) is the difficulty of visualization of the anatomical aspects of the cervical vertebrae, because it seems that there are intermediate stages among the 5 stages considered. In addition, O' Reilly and Yanniello (23) reported that the CVMI evaluation could be hindered by the subtlety of the morphologic alterations that the vertebrae undergo during their growth and by the incorrect position of the patient at the moment the lateral cephalometric radiography is done, which might cause overlapping of the structures, and consequently, difficulty in the evaluation of them. Despite the difficulty of determining within which stage the patient is because of the existence of intermediate stages, San Roman et al. (19) are of the opinion that they do not seem to interfere in the final result.

Corroborating the findings of Paiva et al. (21), who affirmed that the CVMI index is very sensitive no matter the examiner is well calibrated, the classification stage can be erroneously determined, since the threshold between the stages is very subtle.

In agreement with Canali, Brücker and Lima (1), the proposed CVMI is useful and trustworthy, although it is based on a subjective evaluation provoking a certain variability and difficulty of inspection. However, other radiographic methods used to determine the bone maturation present the same difficulty, and have not been invalidated. 
Santos and Almeida (20) and Santos et al. (13) confirmed the applicability of this method, highlighting, however, the difficulty of visualizing the vertebrae on account of the image quality, and proposed that it be complement with the greatest number of resources and available information regarding each individual to allow for a more precise diagnostic.

The unfeasibility of getting an absolute method to safely estimate a patient's skeletal growth and development is unquestionable in literature. Factors such as race, genetic predisposition, diseases, climatic and socioeconomic conditions associated with nutritional aspects, as well as the human evolutionary trend to reach its maturity more precociously each day are responsible for the great variability of the method of evaluation of the general and craniofacial growth of the individual. Therefore the correct clinical procedure is to associate different indicators of maturation to obtain a closest to real diagnostic, once such indicators are among the factors most usually associated with the great variability of the method $(5,17,18)$.

\section{Conclusion}

Based on the results obtained through this study, it can be concluded that:

- Most of the studied samples (75.9\%) were between stage 1 and 8 of the Martins' curve (3);

- Regarding the vertebrae maturation index, $48.1 \%$ were within bone maturation stage 1 and $21.5 \%$, in stage 2, according to Baccetti, Franchi and McNamara Jr. (22);

- There was a statistically significant correlation between the two bone maturation indices (SMI and CVMI);

- There was a moderately positive correlation between the two indices (SMI and CVMI) and the chronological age of the sample studied;

- SMI presents the most trustworthy results according to Spearman and Pearson's correlation test;

- It is suggested that while not yet conversant with the method, the professional be cautious when utilizing CVMI for the determination of skeletal maturity of patients under development.

\section{References}

1. Canali L, Brücker MR, Lima EMS. Avaliação da maturação esquelética das vértebras cervicais através de telerradiografias de perfil. Rev Odonto Ciênc 2003;18:127-37.

2. Araújo TSS. Estudo comparativo entre dois métodos de estimativa da maturação óssea [dissertation]. Piracicaba (SP): Faculdade de Odontologia, Universidade Estadual de Campinas; 2001.

3. Martins, JCR. Surto de crescimento puberal e maturação óssea em Ortodontia [dissertation]. São Paulo (SP): Curso de Pós-Graduação em Ortodontia, Universidade de São Paulo; 1979.

4. Damian MF, Woitchunas FE, Cericato GO, Cechinato F, Moro G, Massochin ME, Castoldi FL. Análise da confiabilidade e da correlação de dois índices de estimativa da maturação esquelética: índice carpal e índice vertebral. Rev Dental Press Ortodon Ortop Facial 2006;11:110-20.

5. Fishman L S. Chronological versus skeletal age, an evaluation of craniofacial growth. Angle Orthod 1979;49:181-9.

6. Generoso R, Tavano O, Ribeiro A, Parreira MLJ. Estudo da correlação entre idade cronológica e a maturação das vértebras cervicais em pacientes em fase de crescimento puberal. Rev Dental Press. Ortodon Ortop Facial 2003;8:19-36.

7. Eło LF, Mazzieiro ÊT. Avaliação da correlação entre os estágios de mineralização dos dentes inferiores e a idade esquelética observados sob o gráfico de crescimento puberal. Rev Dent Press Ortodon Ortop Facial 2005; 10:75-86.

8. Moscatiello VAM, Lederman H, Moscatiello RA, Junior KF, Moscatiello RM. Maturação das vértebras cervicais e sua correlação com a idade óssea da mão e punho como indicadores no tratamento ortodôntico. Rev Dent Press Ortodon Ortop Facial 2008;13:92-100.

9. Fishman LS. Radiographic evaluation of skeletal maturation: a clinically oriented method base on hand-wrist film. Angle Orthod 1982;52:88-112.

10. Caldas MP. Avaliação da maturação esquelética na população brasileira por meio da análise das vértebras cervicais [dissertation]. Piracicaba (SP): Curso de Odontologia, Universidade Estadual de Campinas; 2007.

11. Lara TS, Bertoz FA, Santoss ECA, Bertoz APM. Morfologia das $3^{a}$ e $4^{a}$ vértebras cervicais representativa do surto de cresci- mento puberal. Rev Dent Press Ortodon Ortop Facial 2008;13: 66-76.

12. Tavano $O$. A radiografia carpal como estimador da idade óssea. In: Freitas A, Rosa JE, Souza IF. Radiologia odontológica. São Paulo: Artes Médicas; 2000. p. 611-9.

13. Santos ECA, Bertoz FA, Arantes FM, Reis PMP. Avaliação da reprodutibilidade do método de determinação da maturação esquelética por meio das vértebras cervicais. Rev Dent Press Ortodon Ortop Facial 2005; 10:62-8.

14. Franchi L, Baccetti T, Mcnamara JR, A. Mandibular growth as related to cervical maturation and body height. Am J Orthod Dentofacial Orthop 2000; 1 18:335-40.

15. Armond MC, Castilho JCM, Moraes LC. Estimativa do surto de crescimento puberal pela avaliação das vértebras cervicais em telerradiografias laterais. Ortodontia 2001;34:51-60.

16. Flores-Mir C, Burgess CA, Champney M, Jensen RJ, Pitcher MR, Major PW. Correlation of skeletal maturation stages determined by cervical vertebrae and hand-wrist evaluations. Angle Orthod 2006;76:1-5.

17. Garcia-Fernandez P, Torre H, Flores L, Rhea J. The cervical vertebrae as maturation indicators. J Clin Orthod 1998;32:221-5.

18. Hassel B, Farman AG. Skeletal maturation evaluation using cervical vertebrae. Am J Orthod Dentofacial Orthop 1995; 107:58-66.

19. San Román P, Palma JC, Oteo MD, Nevado E. Skeletal maturation determined by cervical vertebrae development. Eur J Orthod 2002;24:303-1 1

20. Santos SCBN, Almeida RR. Estudo comparativo de dois métodos de avaliação da idade esquelética utilizando radiografias em norma lateral e radiografias carpais. Ortodontia 1999;32:33-45.

21. Paiva GAN, Barbosa RS, Ferreira EEM, Carvalho PEG. Avaliação radiográfica das vértebras cervicais como método para estimativa da maturidade esquelética. Cienc Odontol Brasil 2007;10:54-63.

22. Baccetti T, Franchi L, McNamara JA Jr. An improved version of the cervical vertebral maturation (CVM) method for the assessment of mandibular growth. Angle Orthod 2002;72:316-23.

23. O'Reilly MT, Yanniello GJ. Mandibular growth changes and maturation of cervical vertebrae: a longitudinal cephalometric study. Angle Orthod 1988;58:179-84. 